\title{
DIAGNOSIS OF SUSTAINABILITY IN THE BRAZILIAN CITY OF TOUROS: AN APPLICATION OF THE BAROMETER OF SUSTAINABILITY
}

\author{
G. C. Araújo ${ }^{1}$, H. C. D. Pimenta ${ }^{2}$, L. M. M. Reis ${ }^{3}$, L. M. S. Campos ${ }^{4}$ \\ ${ }^{1 \text { and } 2}$ Nucleus for Sustainable Corporate Studies, Federal Institute of Rio Grande do Norte - NESE/IFRN \\ ${ }^{3}$ Natural Resource Department, Federal Institute of Rio Grande do Norte - DIAREN/IFRN \\ ${ }^{4}$ Production Engineering and Systems Department, Federal University of Santa Catarina - UFSC/DEPS \\ ${ }^{1}$ genibertocesar@gmail.com, ${ }^{2}$ handson.pimenta@ifrn.edu.br, ${ }^{3}$ leci.reis@ifrn.edu.br, ${ }^{4}$ lucila@deps.ufsc.br
}

Artigo submetido em janeiro/2013 e aceito em abril/2013

\begin{abstract}
The present study aimed to analyse the sustainability degree of the Municipality of Touros located in Rio Grande do Norte (Northeast of Brazil) through the "Barometer of Sustainability" methodology, in 2010. This is a descriptive, exploratory and applicative study. The data collection was based on secondary source such as the databases of the Brazilian Institute of Geography and Statistics, the National Confederation of Municipalities, as well as the Institute for Sustainable Development and Environment of Rio Grande do Norte from October, 2010 to July, 2011. Regarding the choice of indicators applied, it was done taking into account the availability of data for the municipality. Hence, the human subsystem (HWI) and ecological (EWI) indicators were: life expectancy,

child mortality, malnutrition, fertility rate, water supply, sanitation, literacy rate, education, literacy, energy consumption, agricultural production, environmental protection area, and vegetable extraction. It was applied thirteen indicators in the Barometer of Sustainability methodology. The degree obtained for the human subsystem was 48 , showing that the municipality is in a satisfactory position. Concerning the ecological subsystem, the situation is potentially sustainable, a value of 67.58 , which means a satisfactory score. Therefore, Touros has a strong potential for sustainability, requiring public policies for health and education and specifically for agricultural production and environmental protection area.
\end{abstract}

KEY-WORDS: barometer of sustainability; Sustainable Development; performance scale.

\section{Análise da sustentabilidade no munícipio brasileiro de Touros (RN): uma aplicação do Barômetro da Sustentabilidade}

\section{Resumo}

O presente estudo tem como objetivo avaliar o índice de sustentabilidade do Município de Touros-RN através da metodologia "Barometer of Sustainability", no ano de 2010. A coleta de dados foi embasada em levantamentos secundários aos bancos de dados do IBGE, da Confederação Nacional de Municípios e do Instituto de Desenvolvimento Sustentável e Meio Ambiente do Rio Grande do Norte no período correspondente a outubro de 2010 e julho de 2011. Para efeito de estudo a escolha dos indicadores envolvidos foram tomados a partir da disponibilidade destes para subsistema humano (HWI) e ecológico (EWI), sendo eles: expectativa de vida, mortalidade infantil, desnutrição, taxa de fertilidade, abastecimento de água, esgoto sanitário, alfabetização, taxa de escolaridade,

analfabetismo, consumo de energia elétrica, produção agrícola, área de proteção ambiental e extração vegetal, perfazendo um total de treze indicadores. 0 grau obtido para o subsistema humano foi de 48 , demonstrando que - município situa-se numa posição satisfatória. Em relação ao subsistema ecológico, a situação é de potencialmente sustentável, com valor de 67,58. Concluindo que o município encontra-se em situação intermediaria dentro do gráfico do "Barometer of Sustainability". Portanto, o município possui um forte potencial para atingir a sustentabilidade, necessitando de políticas públicas voltadas para a área da saúde e educação e especificamente para a produção agrícola e área de proteção ambiental.

PALAVRAS-CHAVES: "barometer of sustainability"; Desenvolvimento sustentável; escala de desempenho 


\section{INTRODUCTION}

The term sustainable development was released, in 1987, by the World Commission on Environment and Development (CMMAD) through the report entitled "Our Common Future" as being "the development which meets the needs of the present without compromising the ability of future generation to meet their own needs" (UNITED NATIONS, 2008).

It is important to note that this development model emphasizes the evolution of human society from the responsible economic point of view, according to environmental and natural processes. In this perspective, the economic and social limitations, as well as those of the natural resources are considered in order to contribute not only to the well-being of the present and future generations, but they can also be applied at a local, regional, and national level based on political will (GLAVIC; LUKMAN, 2006).

In order to discuss the proposals of the report, the United Nations Organization (UNO) held the United Nations Conference on Environment and Development (CNUMAD) in Rio de Janeiro in 1992. This conference consecrated the goals of the Brundtland report, mentioning the relation between poverty and environmental degradation and the need to find new productions and consumption standards for this and the future generations. This conference has also resulted in the production of several important documents that have based themselves on the concept of sustainable development, being that among these documents one highlights the Agenda 21, which consists of an action plan to achieve the objectives of the sustainable development (BARBIERI, 2005; PIMENTA, 2010).

In this sense, it has been seen that the development of tools able to measure the sustainable development of a nation, state or municipality for the last few years in an attempt to evaluate the possibility of improvements of the population's quality of life, besides proving grounding for the formulation of adequate public policies,.

Initially, the Gross Domestic Product (GDP) was a predominant means for the development analysis of a nation. It is valid to remember that the GDP provides the sum of all the wealth produced in a given place, serving as reference for most analyses, not providing sufficient information to evaluate the sustainability of a country, nation or even in smaller scales as a municipality.

In the 1990's, with the enlargement of the concept of development, going from its meaning of mere material progress to the idea of enlargement of freedoms, it was created the need for developing a new indicator, which may serve as a measure for human development. Thus, the United Nations Development Program (UNDP) proposed the Human Development Index (HDI), with the intention of measuring the level of human development of the countries or municipalities from indicators of education (literacy), longevity (life expectancy at birth) and per capita income (GDP), a measurement that ranges from zero to one (UNITED NATIONS DEVELOPMENT PROGRAM, 2011).

In spite of being an evolution in what concerns the mensuration of development, the HDI is limited as a sustainable development indicator; hence it cannot capture the environmental dimension of development (LOUETTE, 2007; VEIGA, 2008).

Several initiatives have been tried to meet the need for a sustainable development indicator, which may equally contemplate the three dimensions of sustainability, namely: the environmental, social, and economic ones. This information is important for both the decision 
making of the public power, through a top down approach, and the construction of citizenship and people's participation, considering that "there is no economic democracy without adequate information about the dynamics and results that really matter" (LOUETTE, 2007).

According to Bellen (2006), the best-known tools to evaluate the level of sustainability through a set of indicators are: "Ecological Footprint Method", "Dashboard of Sustainability", and "Barometer of Sustainability".

In this sense, to justify the importance of the proposed theme, it is valid to highlight the lack of information available for the theme, for dealing with a recent subject. Also, concerning the municipality of Touros, State of Rio Grande do Norte (RN), located in the northeast of Brazil, which presents an HDI of 0.595 , resulting from the problems in education, health, and income of the population reflecting on its development, and also because the municipality presents a lack of studies referring to the "sustainable development" theme. Searching a more detailed comprehension of the situation of the Touros, in the face of sustainability, the present study has departed from the following problem-question: What is the real situation of the municipality in the face of sustainable development from the application of the "Barometer of Sustainability" methodology?

In this context, the present study aimed to apply the "Barometer of Sustainability" methodology in the municipality of Touros (Brazil) for identifying the degree of sustainability by means of the indicators of the human and ecological subsystem.

This work is structured in the following parts followed by this introduction: the main theoretical bases referring to the theme, sustainable development and the methodological aspects applied as to the choice of the place for implantation of the mensuration model and as to the statistic treatment applied to the collected data; discussion and results; and, finally, the references.

\section{SUSTAINABLE DEVELOPMENT}

\subsection{Overview}

The term "sustainable development" (SD) appeared in the 80 's, gaining importance at the global level with the publication of the Brundtland Report (1987). This report points out that sustainable development, in essence, is a change process in which the exploration of resources, the direction of investments, the technological development orientation, and the institutional change are all in harmony and reinforce the current and future potential to meet the human needs and aspirations (UNITED NATIONS, 2008).

In accordance with Robles Jr. and Boneli (2006), there are two pivotal concepts on SD by the Brundtland Report,: firstly, the needs, which can vary from society to society, but which must be satisfied to ensure essential life conditions to all, indistinctly. The second concept is the limitation, which demands the need for the technology to develop solutions that may conserve the limited natural resources currently available and that may allow to renew them insofar as they are necessary to the future generations.

In addition, in all its content, it is argued that the environmental problems resulting from the style of development adopted by the countries as well as suggested a series of measures that 
must be taken by the countries to promote sustainable development (BARROS; AMORIM; CÂNDIDO, 2010).

In spite of being a questionable concept for not defining which the needs of the present are and which those of the future will be, the Report has called the attention of the world to the need to find new forms of economic development, without the reduction of the natural resources and without damages to the environment. Moreover, it has defined three basic principles to be complied with: economic development, environmental protection, and social equity (UNITED NATIONS, 2008).

Even so, the Report has suffered many criticisms, for reporting that the unsustainability of the planet has as culprits the population uncontrol and the misery in the developing countries, putting pollution in second plan (BARBOSA, 2008). According to Sachs (2008), the term Sustainable Development is, many times, utilized only to express environmental sustainability or economic feasibility. However, there are other dimensions that must be considered: social, cultural, ecological, environmental, territorial, economic and political ones.

The report also considers that widespread poverty is no longer inevitable and the development of a town must take into account the meeting of the basic needs of all and offer opportunities of improvement of quality of life for the population. One of the main concepts debated by the report has been the "equity" as a condition for the effective participation of society in the decision-making, through democratic processes, for the urban development.

In addition, the report highlights, in relation to urban issues, the need for decentralization of the application of financial and human resources and the need for the public power to favor the towns in their local scale. Concerning the natural resources, it has analyzed the capacity of the biosphere to absorb the effects caused by human activity and maintained that poverty can already be considered as an environmental problem and as a fundamental topic for the search of sustainability (BARBOSA, 2008).

Some authors have been researching the evolution of the term sustainable development, for example Hill (1998) that illustrated ways in which the principle of sustainable development is being moved on and made operational through a number of tools, techniques and processes and how these are linked. It considers the evolution of sustainable development, European and national environmental legislation, practical approaches to achieving sustainable development at the local level and some tools for action including Local Agenda 21, environmental assessment and environmental management. Another author, Radulescu (2009), presents the conceptual evolution of sustainable development emphasizing its different understanding at various levels ideological, national, European, global, and corporate. According to this author, progress toward sustainability requires the restructuring of conventional decision-making processes and redistribution of classical economic assumptions, at both national and international level. Everything must be examined and determined from complexes legitimate ecological management of environmental resources to ensure full equality between the present and future generation, for solving perspective environmental problems and the transition to a new global ecological development. More recently Quental et al (2011) describes the global political milestones of greater importance to the emergence and evolution of sustainable development.

Other authors present studies of the sustainable development evolution in some regions, such as Ribeiro and Rodrigues (1997), which presented some strategies for sustainable development in Portugal; Nelson (2003) that discuss the evolution of this theme in Canada; and 
Kelly et al (2004) that describe the evolution of sustainable development in Ireland and the generic field of futures thinking, with particular focus on the prospective process which may assist key local policy makers and stakeholders move towards sustainable development for future generations in Ireland.

\subsection{Sustainable Development Indicators}

According to Bellen (2004), an indicator is a tool that permits to obtain information about a given reality. Being so, the indicators are constituted by one or more variables, which, when associated through various forms, reveal the meaning about the phenomena as well as to be essential tool that aims to guide and support the follow-up and evaluation of the progress towards sustainable development (SILVA; CORREIA; CÂNDIDO, 2010).

The objective of the indicators is to aggregate and quantify information in a way that their significance becomes more apparent, simplifying the information about the complex phenomena, trying to improve with this the communication process about them in a more comprehensible and quantifiable manner (BELLEN, 2006). Therefore, the sustainability indicators are utilized as a standard tool in various national and international studies. They have been facilitated the understanding of the information about the complex phenomena besides that acted as a basis for a development analysis that comprises various dimensions. There are currently around 60 indicators that enable to evaluate the level of sustainable development, being disposed in four dimensions: Environmental, Social, Economic, and Institutional (LOUETTE, 2009).

In agreement with Bellen (2004), the criteria taken for the choice of the indicators must be observed in considering the particularities of the place and taking into account the opinion of the consulted researchers and interest groups. The following frame presents some of these criteria for the choice of the indicators (See table 01). Concerning the classification, the sustainability indicators are generally classified as simple or composed indicators. This classification will depend on the complexity of the methodology utilized to create the indicator or the amount of information used in its construction. The simple indicators are built from a single statistic referring to a single dimension. Regarding the composed indicators, which can also be called synthetic indicators or indices, they are built from several (at least two) indicators, of one or more dimensions. The indices are utilized to portray situations of greater complexity, which have several dimensions, as, for example, the concept of well-being, which cannot be reduced to a single indicator or measure, as life expectancy at birth and per capita income (JANNUZZI, 2009).

The indices can also be a form of communicating a great amount of complex information to a lay public. However, the use of an index can cause problems, as masking a low performance in one of the indicators that makes it up. This can occur due to the fact that the other indicators that the indices encompass may present elevated results, which ends up elevating the index score as well. Furthermore, a special care must be given to an index which is made up of indicators that utilize different measures, such as as life expectancy in years and income in cash, which can cause distortions (BOSSEL, 1999; BRAGA, et al, 2005).

Table 01: Criteria for the choice of the indicators to evaluate sustainability

\begin{tabular}{|c|l|}
\hline Criteria & \multicolumn{1}{c|}{ Description } \\
\hline Political relevance & $\begin{array}{l}\text { the indicator must be associated to one or several issues that may be } \\
\text { relevant to the formulation of policies; }\end{array}$ \\
\hline Simplicity & $\begin{array}{l}\text { the information must be presented in a comprehensible and easy } \\
\text { approach to the proposed audience; }\end{array}$ \\
\hline
\end{tabular}




\begin{tabular}{|c|l|}
\hline Validity & the indicators must really reflect the facts; \\
\hline Temporal series of data & $\begin{array}{l}\text { the indicators must seek to observe the tendencies over time, with a } \\
\text { relevant number of data; }\end{array}$ \\
\hline Availability of good-quality data & $\begin{array}{l}\text { there must be currently, or in the near future, good-quality data } \\
\text { available at a reasonable cost; }\end{array}$ \\
\hline Skills for aggregating information & the indicators refer to the dimensions of sustainability; \\
\hline Sensitivity & $\begin{array}{l}\text { the selected indicators must have the capacity of identifying or } \\
\text { detecting changes in the system; }\end{array}$ \\
\hline Reliability & $\begin{array}{l}\text { the indicators must achieve the same result by making two or more } \\
\text { measurements of the same indicator. }\end{array}$ \\
\hline
\end{tabular}

Source: Bellen (2004).

The sustainability indicators can be classified as indicators of Pressure, State, Reply (PSR), a model developed by the Organization for Economic Cooperation and Development (OECD). The state indicators are those which describe the current situation of the natural systems. The pressure indicators have as finality to measure the influence of the anthropic activities in these same systems. And, finally, the reply indicators have as objective to measure the actions of society (e.g. political ones), which may have as finality to reply to these pressures and impacts (BOSSEL, 1999; BRAGA, et al; 2004). Some examples of sustainable indicators will be illustrated in table 02:

\subsection{Barometer of sustainability}

The "Barometer of Sustainability" tool was developed by various specialists linked to two institutes, The World Conservation Union (IUCN) and The International Development Research Centre (IDRC), being Prescott-Allen the main researcher involved in its development. This tool is utilized to measure the progress towards sustainable societies through the combination of various indicators which will provide an analysis of the state of human and the environment through indices (LOUETTE, 2009).

This tool is addressed to the governmental and non-governmental agencies, to public managers, and people involved in issues related to sustainable development, in any level of the system, such as local or global (PRESCOTT-ALLEN, 1997).

The Barometer consists of a combination of dimensions of human and ecological subsystem. Each of them is subdivided into elements and sub-elements that individually provide their respective indices. The indicators involved to make up these indices are chosen only if they can be defined in numerical terms. On the other hand, when they represent a series of different elements, it is necessary to be turned into a common unit in order to avoid some distortions (PRESCOTT-ALLEN, 1997). Therefore, it is suggested that a performance scales may to be use combining these different indicators.

Table 02: Examples of Sustainability Indicators.

\begin{tabular}{|c|l|}
\hline Criteria & \multicolumn{1}{|c|}{ Description } \\
\hline \multirow{3}{*}{ Genuine Progress Indicator (GPI) } & $\begin{array}{l}\text { GPI aims to measure the economic growth of a country linked to the } \\
\text { growth of its inhabitants' well-being. The GPI utilizes the same } \\
\text { methodology as the GDP, and as both express their results in monetary } \\
\text { units, they can be easily compared. The main differences between } \\
\text { these two indicators mainly refer to the fact that they consider as } \\
\text { negative some expenditures that the GDP considers as positive, for }\end{array}$ \\
\hline
\end{tabular}




\begin{tabular}{|l|l|}
\hline \multirow{5}{*}{ Ecological Footprint - EF } & $\begin{array}{l}\text { instance, expenditures related to crime and family failure, pollution, } \\
\text { long-run environmental damages, among others. Besides that they } \\
\text { consider as positive contributions that the GDP ignores, as the domestic } \\
\text { and voluntary work. }\end{array}$ \\
\hline $\begin{array}{l}\text { This indicator aims to establish the degree of utilization of nature by } \\
\text { human being for purposes of production and consumption of materials. } \\
\text { In other words, this indicator seeks to measure if the natural resources } \\
\text { have been used considering the planet capacity to repose them. } \\
\text { Thus, the EF transforms the use of the natural resources (such as, raw } \\
\text { materials supply, absorption of pollutants as well as the regeneration } \\
\text { of this capacity), in a common unit that may be comparable, in this case, } \\
\text { to the productive area (hectares) of the planet. }\end{array}$ \\
\hline Dashboard of Sustainability \\
$\begin{array}{l}\text { This indicator is an aggregate index of several performance indicators } \\
\text { regarding economic, social and environmental issues, which shows, } \\
\text { visually, the advancements of countries towards sustainability by } \\
\text { utilizing the metaphor of a vehicle panel. }\end{array}$ \\
\hline
\end{tabular}

Source: Adapted from: Gadrey; Jany-Catrice (2006); Louette (2007)

According to Prescott-Allen (2001), a performance scale provides a measure of how good a variable is in relation to other variables of the same type. It shows some levels that range from unsustainable at an extreme of the scale, to sustainable, at the other. Thus, the positions of the indicators within this scale will permit the utilization of more appropriate measures for each of the indicators. As a consequence, it is possible to use a combination and joint use of the indicators through a group of performance measures, all utilizing the same general scale (PRESCOTT-ALLEN, 1999). After the application of the indices on the equation, these are presented in a graphic representation that seeks to make clear the understanding and give a general level of the environment and society. In this chart, the vertical and horizontal axis is exposed with their respective indices of the human and ecological subsystem that range from 0 to 100 , and divided into five sections of 20 points each, with a variation of color which ranges from red to green. The intersection point between these indices, represented within the chart, provides a portrait of the sustainability of the system, being able to represent the progress, or not, of a given town, state or nation (PRESCOTT-ALLEN, 2001).

\section{MATERIALS AND METHODS}

\subsection{Brief description of studied area}

The municipality of Touros/RN covers an area of $840 \mathrm{~km}^{2}$, equivalent to $1.54 \%$ of the state surface, and is located at $87 \mathrm{~km}$ from the capital. There is an estimated population of 31.089 inhabitants in Touros (IBGE, 2010) (Figure 1). With a tropical rainy climate and dry summer, the municipality is inserted in a rare geological scenario of unique beauty, with practically virgin beaches covered with fields of dunes, sambaquis, caatinga, and Atlantic Rain forest (IDEMA, 2010). 


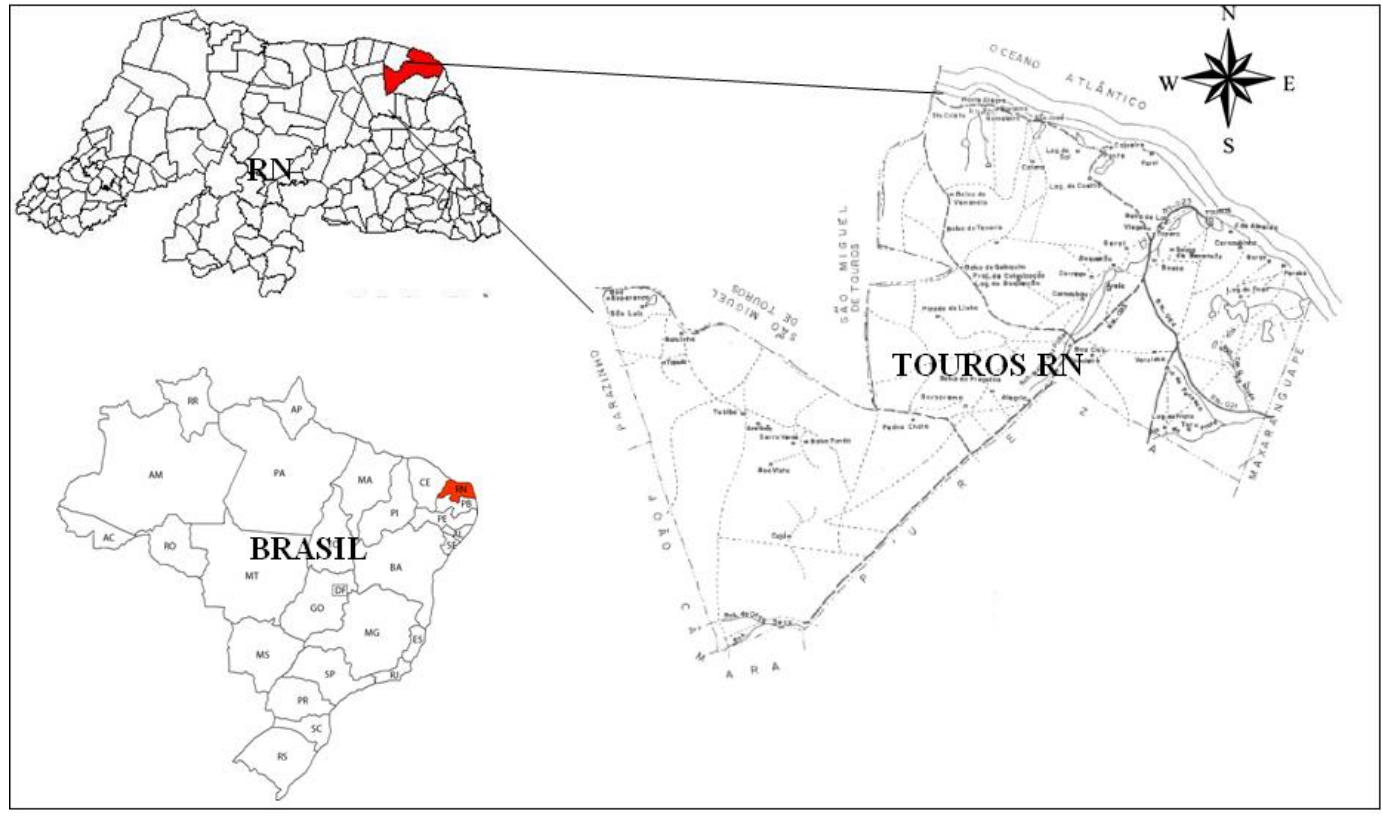

Figure1: Localization map of the municipality of Touros/RN.

In relation to the $\mathrm{HDI}$, the municipality presents an index of 0.595 , being considered a median value according to the classification of the United Nations Development Program (PNUD). The HDI is an important means of expressing in numbers the idea of Human Development of the municipality, for combining three base indicators: the life expectancy at birth and the education level. The development of this indicator has as principle to offer a counterpoint to another very often-utilized indicator that only considers the economic dimension of development, the Gross Domestic Product (GDP), being the variable utilized for its construction the resident population and the per capita GDP itself. For the place in question, the per capita GDP presents a value of $4,742.89$, indicating the population's income level and its variation is a measure of the rhythm of the economic growth (IBGE, 2010).

One of the main economic activities of the municipality is the livelihood culture and fruit production, being highlighted the production of pineapple, cucumber, mango, Bahia coconut, banana, and manioc in small areas. It also presents favorable conditions for the use of agricultural implements, as the cultures of sisal, cashew, and coconut (IDEMA, 2010).

\subsection{Methodological Procedures}

The process of date collection was based on secondary researches from Brazilian Institute of Geography and Statistics (IBGE), the National Confederation of Municipalities, the Atlas of human development of Brazil and the Sustainable Development and Environmental Institute of Rio Grande do Norte (IDEMA) in the period between October of 2010 and July of 2011.

The indicators chosen to apply the methodology "Barometer of Sustainability" on the human and ecological subsystem in this study were: life expectancy, child mortality, malnutrition, fertility rate, water supply, sanitary wastewater, literacy, electric power consumption, agricultural production, area for environmental protection and vegetable extraction. Thus, a total 
of 13 indicators were selected taken into account the criteria of the availability of the existing data for the municipality.

In addition, the selection of the intervals for performance scales had as a criterion the values proposed in the methodology of PRESCOTT ALLEN (2001) (Tables 3 and 4). It is important highlight that the "Barometer of Sustainability" scale is made up of divisions of five sectors of 20 points each, with intervals defined by values from 0 to 100 which represent conditions ranging from unsustainable to sustainable level. Each sector corresponds to a color, which ranges from red to green (Tables 5 and 6 ).

This methodology creates several indices, being the two main ones the Human Wellbeing Index (HWI) and the Ecological Wellbeing Index (EWI), both comprising the non-weighted average of the dimensions involved, permitting at the end of all to analyze the interaction between these two indices.

The third index and the most important one of this methodology is the Well-Being Index (WI). It deals with a chart in which the Human and Ecological well-being indices are plotted in the chart from their respective axes. The intersection between Axis $Y$ and Axis $X$ within the chart provides a measure of sustainability or unsustainability of the system. This index is evaluated according to the result of the two indices, previously mentioned, and it can be classified the following way.

After calculating the score of the indicators within the barometer scale, they can be grouped to form indices. The indices are formed by always following the inverse order of the hierarchy in which they have been created. Therefore, indicators form the index of a subelement, the indices of the sub-elements combine themselves to form the index of an element, the indices of several elements combine themselves to form the one-dimensional index and, finally, the indices of the dimensions combine themselves to form the system index. The aggregation of these indicators in indices, after the calculations, is made through averages between the indices of the elements and between the indices of the sub-elements, coming, thus, to the system index.

Table 3: Human subsystem indicators.

\begin{tabular}{|c|c|c|c|c|c|c|c|}
\hline \multirow{3}{*}{ Indicators } & \multirow{3}{*}{ Source } & \multirow{3}{*}{ Interval } & \multicolumn{5}{|c|}{ Scale of the Barometer of Sustainability } \\
\hline & & & $0-20$ & $21-40$ & $41-60$ & $61-80$ & 81-100 \\
\hline & & & Unsustainable & $\begin{array}{c}\text { Almost } \\
\text { Unsustainable }\end{array}$ & Medium & $\begin{array}{c}\text { Almost } \\
\text { Sustainable }\end{array}$ & Sustainable \\
\hline Life expectancy $^{1}$ & SIS 2010 & {$[30 ; 85]$} & $30-45$ & $45-60$ & $60-70$ & $70-75$ & $75-85$ \\
\hline Child mortality $^{2}$ & SIS 2010 & {$[360 ; 0]$} & $360-180$ & $180-90$ & $90-45$ & $45-22$ & $22-0$ \\
\hline Malnutrition & $\begin{array}{l}\text { Brasil IDS, } \\
2010\end{array}$ & {$[100 ; 0]$} & $100-50$ & $50-35$ & $35-20$ & $20-10$ & $10-0$ \\
\hline Literacy $^{3}$ & SIS 2010 & {$[0 ; 100]$} & $0-30$ & $30-60$ & $60-80$ & $80-90$ & $90-100$ \\
\hline Schooling rate ${ }^{4}$ & SIS 2010 & {$[20 ; 100]$} & $20-60$ & $60-80$ & $80-90$ & $90-95$ & $95-100$ \\
\hline $\begin{array}{l}\text { Functional } \\
\text { illiteracy }\end{array}$ & SIS 2010 & {$[100 ; 0]$} & $100-90$ & $90-80$ & $80-60$ & $60-30$ & $30-0$ \\
\hline Fertility rate & SIS 2010 & {$[8,2 ; 1,2]$} & $8,2-5,0$ & $5,0-3,4$ & $3,4-2,6$ & $2,6-2,2$ & $2,2-1,2$ \\
\hline Water supply & $\begin{array}{c}\text { Brasil IDS, } \\
2010\end{array}$ & {$[0 ; 100]$} & $0-50$ & $50-65$ & $65-80$ & $80-90$ & $90-100$ \\
\hline
\end{tabular}




\begin{tabular}{l|c|c|c|c|c|c|c}
\hline $\begin{array}{l}\text { Sanitary } \\
\text { wastewater }\end{array}$ & SIS 2010 & {$[0 ; 100]$} & $0-50$ & $50-65$ & $65-80$ & $80-90$ & $90-100$ \\
\hline 1
\end{tabular}

${ }^{1}$ Life expectancy in years;

${ }^{2}$ Number of dead children in 1.000 living ones.

${ }^{3}$ Literacy rate of people aged 15 years or over.

${ }^{4}$ Schooling rate between 6 and 14 years of age.

${ }^{5} 15$ years of age or over.

*Source: PRESCOTT ALLEN (2001).

Table 4: Ecological subsystem indicators.

\begin{tabular}{|c|c|c|c|c|c|c|c|}
\hline \multirow{3}{*}{ Indicators } & \multirow{3}{*}{ Source } & \multirow{3}{*}{ Interval } & \multicolumn{5}{|c|}{ Scale of the Barometer of Sustainability } \\
\hline & & & $0-20$ & $21-40$ & $41-60$ & $61-80$ & 81-100 \\
\hline & & & Unsustainable & $\begin{array}{c}\text { Almost } \\
\text { Unsustainable }\end{array}$ & Medium & $\begin{array}{c}\text { Almost } \\
\text { Sustainable }\end{array}$ & Sustainable \\
\hline $\begin{array}{l}\text { Electric power } \\
\text { consumption }{ }^{1}\end{array}$ & $\begin{array}{l}\text { Statistic } \\
\text { annuary }\end{array}$ & {$[640 ; 0]$} & $640-320$ & $320-160$ & $160-80$ & $80-40$ & $40-0$ \\
\hline $\begin{array}{l}\text { Agricultural } \\
\text { production }^{2}\end{array}$ & $\begin{array}{l}\text { Statistic } \\
\text { annuary }\end{array}$ & {$[0 ; 16]$} & $0-1$ & $1-2$ & $2-4$ & $4-8$ & $8-16$ \\
\hline Protection area & $\begin{array}{l}\text { Statistic } \\
\text { annuary }\end{array}$ & {$[0 ; 40]$} & $0-2,5$ & $2,5-5$ & $5-10$ & $10-20$ & $20-40$ \\
\hline $\begin{array}{l}\text { Vegetable } \\
\text { extraction }\end{array}$ & $\begin{array}{l}\text { Statistic } \\
\text { annuary }\end{array}$ & {$[160 ; 0]$} & $160-80$ & $80-40$ & $40-20$ & $20-10$ & $10-0$ \\
\hline
\end{tabular}

${ }^{1}$ Consumption of power per hectare of the total area $(\mathrm{Gj})$.

${ }^{2}$ Agricultural production of pineapple, herbaceous cotton, sweet potato, beans (in grains), manioc, water melon, corn (in grains), graniferous sorghum (in grains) and tomato per metric ton.

*Source: PRESCOTT ALLEN (2001).

For purposes of calculation, it was used two equations, one for the indicator of the smaller the value, the better the result (Equation 1). And another for the indicator of the bigger the value, the better the result (Equation 2). The equations for calculating the indicators involved are exposed immediately as follows:

$P I B S=\left\{\left[\frac{(V R I-B I S)}{(T I S-B I S)}\right] \times 20\right\}+B B S$

Where:

PIBS: The indicator score in the barometer scale

VRI: Real value of the indicator

BIS: Base value of the range in which the indicator fits itself in the indicator scale (Base Indicator Scale).

TIS: Value of the upper limit of the range in which the indicator fits itself in the indicator scale (Top Indicator Scale).

BBS: Base point of the range in which the indicator fits itself in the barometer scale (Base barometer scale).

$P I B S=T B S-\left\{\left[\frac{(V R I-B I S)}{(T I S-B I S)}\right] \times 20\right\}$

Where:

PIBS: Indicator score in the barometer scale

VRI: Real value of the indicator

BIS: Base value of the range in which the indicator fits itself in the indicator scale.

TIS: Value of the upper limit of the range in which the indicator fits itself in the indicator scale. 
TBS: Point of the upper limit of the range in which the indicator fits itself in the barometer scale.

For the calculation of the indices of the dimensions, it was made an arithmetic average of the score of the indicators. Also, the calculation of the System index, it was made an average of the values of the indices of the dimensions.

\section{RESULTS AND DISCUSSION}

\subsection{Human Wellbeing Index}

According to the "Barometer of Sustainability", the degree obtained for the human wellbeing index (HWI) which achieved 48 points, demonstrated that the dimension of health, nutrition, population, knowledge, and needs of the municipality were in a satisfactory position (Table 5).

This dimension had some values of indicators with high level of variation. For instance, child mortality and water supply achieved a good level of sustainability with 85.09 and 84.4 points respectively. On the other hand, fertility rate and malnutrition achieved fair sustainable level with 75 and 67.8, respectively. Finally, sanitary (wastewater) and life expectance had the worst score achieved with 15.56 (Bad unsustainable level) and 58.2 (medium) respectively.

This fact can be easily identified by the lack of sanitation in the town, being clear the pollution of the water resources such as the rivers and streams that cross the town. Therefore, this situation of the absence or deficiency of sanitation service for the locality result in precarious health conditions for the population.

The indicators related to dimension of Knowledge achieved bad (Illiteracy) or poor (Literacy and schooling rate) level of sustainability. Thus, this dimension was in general in poor level of sustainability with just 29.91 points. Thus, it can be noted the very bad conditions that the municipality has in terms of education, being a potentially unsustainable dimension.

Table 5: Human wellbeing index

\begin{tabular}{|c|c|c|c|c|c|c|c|}
\hline Dimensions & Elements & $\begin{array}{c}\text { Sub- } \\
\text { elements }\end{array}$ & Indicators & $\begin{array}{l}\text { Value } \\
\text { Found }\end{array}$ & $\begin{array}{c}\text { Score of the } \\
\text { indicators }\end{array}$ & $\begin{array}{l}\text { Indices of the } \\
\text { dimensions }\end{array}$ & $\begin{array}{l}\text { Human } \\
\text { wellbeing } \\
\text { Index } \\
\text { (HWI) }\end{array}$ \\
\hline \multirow{6}{*}{$\begin{array}{c}\text { Health, } \\
\text { nutrition, } \\
\text { population } \\
\text { and needs }\end{array}$} & \multirow{2}{*}{ Health } & Longevity & $\begin{array}{c}\text { Life } \\
\text { expectancy }\end{array}$ & 60.9 & 58.2 & \multirow{6}{*}{$\begin{array}{c}\text { 66,34 } \\
\text { (Fair } \\
\text { sustainable) }\end{array}$} & \multirow{9}{*}{$\begin{array}{c}48 \\
\text { (Medium) }\end{array}$} \\
\hline & & $\begin{array}{l}\text { Lost life } \\
\text { time }\end{array}$ & $\begin{array}{c}\text { Child } \\
\text { mortality }\end{array}$ & 16.4 & 85.09 & & \\
\hline & Nutrition & $\begin{array}{c}\text { Food } \\
\text { insuficiency }\end{array}$ & Malnutrition & 16.1 & 67.8 & & \\
\hline & Population & Procreation & Fertility rate & 2.3 & 75 & & \\
\hline & \multirow[b]{2}{*}{ Needs } & \multirow{2}{*}{$\begin{array}{c}\text { Basic } \\
\text { services }\end{array}$} & Water supply & 97,8 & 84.4 & & \\
\hline & & & $\begin{array}{c}\text { Sanitary } \\
\text { wastewater }\end{array}$ & 11.1 & 15.56 & & \\
\hline \multirow{3}{*}{ Knowledge } & \multirow{3}{*}{ Knowledge } & \multirow{3}{*}{ Education } & Literacy & 68 & 32 & \multirow{3}{*}{$\begin{array}{c}\text { 29,91 } \\
\text { (Poor } \\
\text { unsustainable) }\end{array}$} & \\
\hline & & & $\begin{array}{l}\text { Schooling } \\
\text { rate }\end{array}$ & 80.9 & 38.2 & & \\
\hline & & & Illiteracy & 30.7 & 19.53 & & \\
\hline
\end{tabular}




\subsection{Ecological Wellbeing Index}

With regard to the ecological wellbeing index (EWI), there were occurred moderate changes, remaining in the potentially sustainable position, with the value of 64.93 , being a reasonable indication (Table 6).

This subsystem is divided into the dimensions of use of resources and soil, where the energy element obtained a rather satisfactory result. The best performance observed among all the other elements in this research was related to energy which represented a value of 99.96 .

Other elements analyzed in ecological subsystem were soil protection, which was divided into the sub-elements, planted area, conservation unit and de-forestation. It could be noted a satisfactory result for vegetable extraction, with 61.2. On the other hand, the other sub-elements decreased considerably the average of the dimension soil hence the indicators agricultural production and environmental protection area just reached 18.2 and 43.2, making the dimension soil poor unsustainable with a score of 29.91 .

Concerning the indicator for agricultural production which represented the worst index for this subsystem, Kronemberger, et al (2008), who studied sustainability in Brazil, verified that the Brazilian ecological subsystem is in a situation below the one of the said study, demonstrating that, according to the methodology and the indicators chosen, the sustainability of the country is very low.

Table 6: Ecological wellbeing index.

\begin{tabular}{|c|c|c|c|c|c|c|c|}
\hline Dimensions & Elements & $\begin{array}{l}\text { Sub- } \\
\text { elements }\end{array}$ & Indicators & $\begin{array}{l}\text { Value } \\
\text { found }\end{array}$ & $\begin{array}{l}\text { Score of the } \\
\text { indicators }\end{array}$ & $\begin{array}{c}\text { Indices of } \\
\text { the } \\
\text { dimensions }\end{array}$ & $\begin{array}{c}\text { Ecological } \\
\text { wellbeing } \\
\text { Index } \\
\text { (EWI) }\end{array}$ \\
\hline $\begin{array}{l}\text { Use of } \\
\text { resources }\end{array}$ & Energy & Energy & $\begin{array}{c}\text { Electric } \\
\text { power } \\
\text { consumption }\end{array}$ & 0.08 & 99.96 & $\begin{array}{c}99.96 \\
\text { (Good } \\
\text { Sustainable) }\end{array}$ & \multirow{4}{*}{$\begin{array}{c}64.93 \\
\text { (Fair } \\
\text { sustainabl } \\
\text { e) }\end{array}$} \\
\hline \multirow{3}{*}{ Soil } & $\begin{array}{l}\text { Producti } \\
\text { on }\end{array}$ & $\begin{array}{l}\text { Planted } \\
\text { area }\end{array}$ & $\begin{array}{l}\text { Agricultural } \\
\text { production }\end{array}$ & 0.09 & 18.2 & \multirow{3}{*}{$\begin{array}{c}29.91 \\
\text { (Poor } \\
\text { unsustainable) }\end{array}$} & \\
\hline & \multirow{2}{*}{$\begin{array}{c}\text { Soil } \\
\text { protection }\end{array}$} & $\begin{array}{c}\text { Conservation } \\
\text { unit }\end{array}$ & $\begin{array}{l}\text { Environment } \\
\text { al protection } \\
\text { area }\end{array}$ & 21.6 & 43.2 & & \\
\hline & & $\begin{array}{c}\text { De- } \\
\text { foresting }\end{array}$ & $\begin{array}{l}\text { Vegetable } \\
\text { extraction }\end{array}$ & 19.4 & 61.2 & & \\
\hline
\end{tabular}

Concerning the indicator for agricultural production which represented the worst index for this subsystem, Kronemberger, et al (2008), who studied sustainability in Brazil, verified that the Brazilian ecological subsystem is in a situation below the one of the said study, demonstrating that, according to the methodology and the indicators chosen, the sustainability of the country is very low. 
Therefore, the combination of the three indicators resulted in four dimensions, which enabled the formation of eight elements. As a consequence, ten sub-elements provided the human and ecological subsystem index (Tables 5 and 6).

After that, these indices were plotted in the barometer chart in order to establish the sustainable level of municipality of Touros/RN (Figure 2). Thus, it can be noted that Touros is in a medium level of sustainability according to Barometer of sustainability methodology. If the Brazilian reality is taken into account in studies of Prescott-Allen (2001) and Kronemberger (2008), which showed that Brazilian HWI achieved 45 and 44 points, respectively, it can be observed that Touros is relatively in a better position.

Figure 2: Position of the Municipality of Touros-RN in the Barometer of Sustainability.

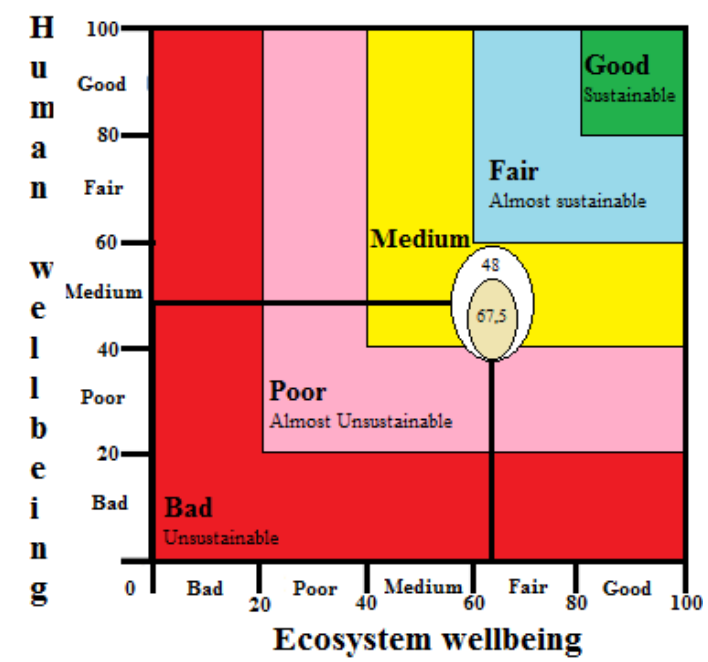

\subsection{Wellbeing Stress Index}

Regarding the index of wellbeing/stress (WSI) which is a relation between the value of $\mathrm{HWI}$ and the stress caused in ecosystem. This means that when the HWI achieves a good score, more benefits are reached by society with a decrease of environmental impacts. Thus, the EWI is calculated in two steps: firstly, Ecological stress index (ESI) is calculated according the equation 03 bellow whereby HWI is subtracted of 100 . After that, the WSI is calculated by ratio between $\mathrm{HWI}$ and ESI (Equation 4).

$E S I=100-E W I$

Where:

ESI: Ecological stress index

EWI: Ecosystem wellbeing Index

$W S I=\frac{H W I}{E S I}$

Where:

ESI: Ecological stress index

WSI: Wellbeing / stress index

HWI= Human Wellbeing Index 
Therefore, it can be noted that the ESI is 35.07 (100-64.93) and, therefore, WSI is 1.37 . According to Prescott-Allen (2001), a good result to index of wellbeing/stress is at least 4 which means Human wellbeing is 4 times bigger than the stress caused in nature. In addition, it is a medium value the score 2 . Therefore, it can be seen that the human wellbeing is just 1.37 time bigger than the stress caused in natural system. This can be considered a poor performance.

\section{CONCLUDING REMARKS}

The use of indicators and indices is important to plan, achieve and assess actions toward sustainable development, since it is necessary for society, knowing where they are in pursuit of that goal. Despite the need to simplify a complex reality in order to make it easier to understand, the construction of indices is hard activity because it tries to present in one or a limited set of data, a multifaceted reality. Besides that, the choice of indicators, their methods of creation and aggregation, and even to measure, are influenced by values and ideologies and, therefore, they can never be considered a perfect reality. These limitations, however, do not invalidate the usefulness of indicators in planning and policy formulation.

In this context, this study aimed to evaluate the situation the city of Touros in Rio Grande do Norte, facing the sustainable development through the application of the methodology of Barometer of sustainability.

In is important to highlight that the application of this methodology in a local scale has been advantageous for enabling the definition of performance scales for each indicator, attributing them values that represent conditions from unsustainable to sustainable. Also, it was possible to analyze the meaning of each indicator isolated for the sustainable development as well as its distance in relation to established goals, according to the chosen method.

The construction process has occurred from the choice of the indicators to the final aggregation of the themes, resulting in the synthesized presentation of important information to society and the public managers.

Concerning the results, it can be noted that the municipality of Touros-RN, in the year of 2010, was in a medium level of sustainability according to Barometer of sustainability. Regarding the HWI which achieve 48 point, it can be not a huge variation of values of indicators basically achieving since good sustainable level (child mortality and water supply) to bad level of sustainability (sanitation and Illiteracy).

With regard to EWI which reached 64.93 points, it can be seen the same trend of a vast difference among the values of indicator. Energy was the best indicator with a good level of sustainability. On the other side, agricultural production and environmental protection area had medium and poor sustainable level, respectively.

Thus, it can be concluded that this huge variety of result of indicators left the average of indices with a large standard deviation. Also, it can be noted some drawbacks related to the available indicators and their organization by elements and sub-elements.

It is also important to highlight that the wellbeing /stress index was just 1.37 , that means that Human wellbeing is 1.37 time bigger than the stress caused in natural system. 
Finally, it can be concluded that Touros has a strong potential to achieve sustainability. For that, it is necessary the development of public policies related to the areas of health and education and, specifically, to the agricultural production and the area of environmental protection (sanitation).

\section{REFERENCES}

BARBIERI, J. C. Desenvolvimento e Meio Ambiente: as estratégias de mudança da Agenda 21.7. ed. Ver. e atual. Petrópolis, RJ. 2005.

BARBOSA, G. S. O Desafio do Desenvolvimento Sustentável. Revista Visões 4á Edição, №4, Volume 1 - Jan/Jun. 2008.

BARROS, R. A.; AMORIM, B. P.; CANDIDO, G. A. Análise da sustentabilidade municipal: uma aplicação do Barometer of sustainbility em Campina Grande-PB. In: CANDIDO, G. A. (Org). Desenvolvimento Sustentável e Sistemas de Indicadores de Sustentabilidade: Formas de aplicações em contextos geográficos diversos e contingências específicas. Campina Grande - PB: Ed. UFCG. 2010.

BELLEN, H. M. Sustainable development: presenting the main measurement methods. Ambient and Society, Campinas, 2004. v.7, n.1, p.67-87, jan./jun. 2004.

- Indicadores de sustentabilidade: uma análise comparativa. 2․ed. Rio de Janeiro: Fundação Getúlio Vargas, 2006.

BOSSEL, H. Indicators for sustainable development: Theory, method, applications. Manitoba, 1999. The Electronic Farmer: < http://www.ulb.ac.be >. Last accessed: 20 fev. 2011.

BRAGA, B. Introdução à engenharia ambiental: o desafio do desenvolvimento sustentável. São Paulo: Pearson Prentice Hall. 2005.

BRAGA, T. M.; FREITAS, A. P. G.; DUARTE, G. S.; SOUZA, J.C. Índices de sustentabilidade municipal: o desafio de mesurar. Nova Economia Belo Horizonte, 14, n. 3, Set./Dez. 2004. 11 33. 2011.

GADREY, J.; JANY-CATRICE, F. Os Novos Indicadores de Riqueza. São Paulo: SENAC São Paulo. 2006.

GLAVIC, P; LUKMAN, R. Review of sustainability terms and their definitions. Journal of Cleaner Production, v. 15, p. $1875-1885,2007$.

HILL, D. Sustainable development-tools and techniques for action. Proceedings of the Institution of Civil Engineers: Municipal Engineer ,127 (4) , p.165-169. 1998.

INSTITUTO BRASILEIRO DE GEOGRAFIA E ESTATISTICA. Censo Demográfico 2010. Indicadores Sociais. Resultados da Amostra. 2010. The Electronic Farmer: 〈http://www.ibge.gov.brı. Last accessed: 13 de fev. 2011.

SIS 2010 (Síntese de Indicadores Sociais: Uma analise das Condições de Vida da População Brasileira 2010 de desenvolvimento sustentável). Estudos e Pesquisas Informação Demográfica e Socioeconômica número 27. Rio de Janeiro. 2010.

. IDS Brasil 2010 (Indicadores de desenvolvimento sustentável: Brasil 2010/IBGE). Rio de Janeiro 2010. 443 p. 
INSTITUTO DE DESENVOLVIMENTO SUSTENTAVEL E MEIO AMBIENTE DO RIO GRANDE DO NORTE. Atlas para o Desenvolvimento Sustentável do RN 2010. Last accessed: 〈http://www.idema.rn.gov.b〉. Last accessed: 20 out. de 2010.

JANNUZZI, P. D. M. Indicadores sociais no Brasil: conceitos, fontes de dados e aplicações. 4으 Edição. ed. Campinas: Alínea Editora. 2009.

KELLY, R. SIRR, L. RATCLIFFE, J. Futures thinking to achieve sustainable development at local level in Ireland, Foresight, Vol. 6 Iss: 2 p.80-90. 2004.

KRONEMBERGER, D. M. P., JUNIOR, J. V., NASCIMENTO, J. A.S., COLLARES, J. E. R., SILVA, L. C. D. Desenvolvimento Sustentável no Brasil: Uma Análise a Partir da Aplicação do Barômetro da Sustentabilidade. Sociedade \& Natureza, Uberlândia. Sociedade \& Natureza, Uberlândia. 2008.

LOUETTE, A. Indicadores de Nações: uma Contribuição ao Diálogo da Sustentabilidade. São Paulo: WHH - Willis Harman House, 2007.

NELSON, C. Sustainable Development: evolution of the Canadian approach. Environmental Progress, Vol. 22, No. 4, p.293-295. 2003.

PIMENTA, H. C. D. Sustentabilidade Empresarial: Desafios, Conceitos e Instrumentos. In: PIMENTA, H. C. D. (Org.). Sustentabilidade empresarial: práticas em cadeias produtivas. 1 ed. Natal: IFRN, v. 1, p. 21-52. 2010.

PRESCOTT-ALLEN, R. Barometer of stability. 2010. Last accessed: <http://www.icsuscope.org/downloadpubs/scope58/box2j.html>. Last accessed: 15 out. 2010.

Barometer of Sustainability: Measuring and communicating wellbeing and sustainable development.Cambridge: IUCN. 1997.

Assessing Progress Toward Sustainability: The System Assessment. Method illustrated by the Wellbeing of Nations. Cambridge: IUCN. 1999.

- The Wellbeing of Nations: a country-by-country index of quality of life and the environment.Washington: Island Press. 2001.

PROGRAMA DAS NAÇÕES UNIDAS PARA O DESENVOLVIMENTO. Novo Atlas do Desenvolvimento Humano no Brasil. Last accessed: «http://www.pnud.org.brı. Acesso em: 28 de abr. 2011.

QUENTAL, N.; LOURENÇO, J.M.; SILVA, F.N. Sustainable Development Policy: Goals, Targets and Political Cycles. Sustainable Development, vol. 19, p.15-29. 2011.

RADULESCU, C.V. Towards an ecologically sustainable economy?. Metalurgia International 14 (SPEC. ISS. 5) , p. 146-149. 2009.

RIBEIRO, T.G, RODRIGUES, V.J. The evolution of sustainable development strategies in Portugal. Environmental Politics. 6 (1) , p.108-129. 1997.

ROBLES JR, A; BONELI, V. V. Gestão da qualidade e do meio ambiente: enfoque econômico, financeiro e patrimonial. São Paulo: Atlas, 112 p. 2006.

SACHS. I. Desenvolvimento, includente, sustentável, sustentado. Rio de Janeiro. Editora Garamond, 2008.

SILVA, A. M.; CORREIA, A. M. M.; CANDIDO, G. A. Ecological footprint method: Avaliação da sustentabilidade no município de João pessoa-PB. In: CÂNDIDO, G. A. (Org). Desenvolvimento 
Sustentável e Sistemas de Indicadores de Sustentabilidade: Formas de aplicações em contextos geográficos diversos e contingências específicas. Campina Grande - PB: Ed. UFCG, Cap. 8. p 469. 2010.

UNITED NATIONS. Un Documents Cooperation Circles Gathering. A Body of Global Agreements. Report of the World Commission on Environment and Development: Our Common Future. Last accessed: < http://www.un-documents.net/ocf-02.htm\#l > Last accessed: 10 jan. 2008

VEIGA, J. E. D. Desenvolvimento sustentável: o desafio do século XXI. 3a Edição. ed. Rio de Janeiro: Garamond. 2008. 